\title{
"I Discovered I Love to Pray Alone Too": Pluralist Muslim Women's Approaches to Practicing Islam during and after Ramadan 2020
}

\author{
Anna Piela ${ }^{1, *}$ and Joanna Krotofil ${ }^{2}$ (D) \\ 1 Department of Religious Studies, Northwestern University, Crowe Hall 4-134, 1860 Campus Drive, \\ Evanston, IL 60208, USA \\ 2 Institute of Religious Studies, Jagiellonian University, ul. Grodzka 52, 31-044 Kraków, Poland; \\ joanna.krotofil@uj.edu.pl \\ * Correspondence: anna.piela@northwestern.edu
}

Citation: Piela, Anna, and Joanna Krotofil. 2021. “I Discovered I Love to Pray Alone Too": Pluralist Muslim Women's Approaches to Practicing Islam during and after Ramadan 2020. Religions 12: 784. https://doi.org/ $10.3390 /$ rel12090784

Academic Editor:

Magdalena Szaflarski

Received: 28 July 2021

Accepted: 12 September 2021

Published: 17 September 2021

Publisher's Note: MDPI stays neutral with regard to jurisdictional claims in published maps and institutional affiliations.

Copyright: (c) 2021 by the authors. Licensee MDPI, Basel, Switzerland. This article is an open access article distributed under the terms and conditions of the Creative Commons Attribution (CC BY) license (https:// creativecommons.org/licenses/by/ $4.0 /)$.

\begin{abstract}
Public health guidelines implemented during the COVID-19 pandemic have changed the way many people practice religion. In the realm of Islam, practices from the margins-attending online mosques and prayer groups, or praying alone-suddenly became commonplace. This paper addresses the question: What religious processes have become more evident among pluralist Muslim women during the pandemic? Based on 34 open-ended online surveys completed by pluralist Muslim women living chiefly in the USA and the UK, our analysis evidences the existence of four narratives that reflect fluctuations in the intensity and type of religious practice. The first and most prominent narrative in our dataset conveys enthusiastic embrace of social-distanced practices; the second describes a profound sense of aberration impossible to overcome in spiritual ways. The third highlights that for some Muslims, the pandemic brought no changes, as they continued to be isolated from their communities. The fourth is focused on an affirmation of a "remote" sociality experienced online. While some respondents acknowledge the increased individuation in their religious practice, they also find fulfilment in collective, if transformed, sociality. The changes in social interaction have led to a re-evaluation of salient aspects of their religious identity or, alternatively, highlighted longstanding modalities of exclusion.
\end{abstract}

Keywords: Islam; Muslim; women; pluralist lived religion; COVID-19; social distancing; isolation; online mosques

\section{Introduction}

In 2020, it was impossible to celebrate Ramadan as usual due to the high risk of COVID-19 infection. The USA and the UK, along with many other countries, were in lockdown. Only a few months into the pandemic, it was unclear what the transmission routes were for the coronavirus, but large indoor gatherings were considered dangerous. Inevitably, Muslims were going to have to settle for more private ways to experience Ramadan practices. Popular media (Hussain and Anderson 2020) and community activists (Makki 2020) commented extensively on the gendered aspect of the new religious reality-now Muslim men would be affected by the exclusion from the collective institutional worship, a commonplace experience for many Muslim women before the pandemic. American women's engagement with mosques is often restricted by the prevalence of small, uninviting sex-segregated women's spaces (Haddad et al. 2006; Prickett 2015), or, as noted by some of our participants, patriarchal views and dynamics within the mosques.

We began this study with the hypothesis that the pandemic and the subsequent lockdown would affect the ways people practice Islam, especially given the importance of collective practice for Muslims; although for different groups, the reasons for this may be different. For example, Thompson (2020) noted how important in-person, collective 
corporeal prayer was for many nonconformist Muslims a site of unlearning the old religious habitus, which may include the expectation of sex segregation in mosques, and re-training the new habitus that involves participating comfortably mixed-gender prayer. For many, especially converts or those away from family, mosques may be the only place where they can experience "togetherness" in faith, especially during Ramadan, a period of increased mosque attendance, when the additional, nighttime taraweeh prayer is offered (Salem 2017). For them, the absence of community prayer and celebrations could potentially create a space for new modes and foci of engagement.

In our article, we focus on changes in religious and/or spiritual practice triggered by the COVID-19 pandemic among a population of Muslim women (including some trans and queer Muslim women) who are notoriously difficult to precisely define in terms of belonging and practice. By far, it is easier to define them by who they are not, and what they do not do. Although all participants self-identify as Muslim, we would ask "what kind of Muslim?". Their beliefs and practices are diverse, with no one set of values being dominant. To address that issue, we draw from Wittgenstein's ([1953] 1968, p. 31) idea of games: "if you look at [the class of activities called games] you will not see something that is common to all, but similarities, relationships, and a whole series of them at that; (...) [games] need display no more than 'family resemblances': a complicated network of similarities overlapping and criss-crossing".

An ambivalent attitude to religious "perfectionism" in the sense of striving for allencompassing pious comportment as described by Mahmood $(2001,2005)$ is one of the characteristics of this population. Instead, the interest in and realization of Islamic practice are fostered within the restrictions of everyday life; in Jeldtoft's study (Jeldtoft 2011) such reconfigured practice encompassed praying two, rather than five times a day, or fasting at weekends only during Ramadan. This approach is connected to another characteristicindependent practice in the privacy of one's home, rather than in public spaces or places of collective worship. Further, for some participants, we identified a shifted locus of practice, that is, praying "within one's mind", in thoughts and emotions, rather than following the traditional prayer movements ( $r a k^{\prime} a$ cycles). Jeldtoft (2011) also found that individuals may have internal conversations with God and ponder their connection to Islam through a set of ethical values. Conversely, many others engage with Islamic texts and history which they approach from a feminist hemeneutics perspective. Four, some individuals may integrate spiritual practices from another Islamic tradition (for example, through theological bricolages combining Sunnism and Shi'ism, or Sufism and Salafism), or occupying contested positions within Islam that involve integration of meditation, yoga, or Reiki (Jeldtoft 2011; Amini and Ouassini 2020). The fifth characteristic is related to an investment in social justice, or, in Safi's words (Safi 2003, p. 48), a "pluralistic epistemology, which freely and openly draws from sources outside of Islamic tradition which can serve as useful tools in the global pursuit of justice". This approach can be expressed by affirmation of racial, sexual, environmental, and economic justice.

Thus, respondent $A$ in our study could share reconfigured Islamic practices with respondent $B$, and explicit social justice commitments with respondent $C$; $B$ and $D$ could both be practitioners of yoga, and so forth. For the purpose of this study, we chose to refer to the respondents as "pluralist Muslims", to emphasize their inclusivity and openness to difference (which is variously expressed as affirmation of different branches/sects of Islam, different religious, belief systems, and social causes). Yet, borrowing from Wittgenstein, we did not identify a particular practice that is "common to all", thus requiring us to declare that the label "pluralist Muslims" is tentative, preliminary, and enforced by the academic convention that the object of study be defined and labeled. It speaks to the definition of pluralism proposed by Eck (2001, pp. 70-72):

Pluralism ... is not just another word for diversity. It goes beyond mere plurality or diversity to active engagement with that plurality ... Pluralism is the dynamic process through which we engage with one another in and through our very deepest differences ... It does not displace or eliminate deep religious 
commitments or secular commitments for that matter. It is, rather, the encounter of commitments ... Such dialogue is aimed not at achieving agreement, but at achieving relationship.

While Eck's work is often used to frame interfaith/interreligious relations, it is also useful when considering intrafaith relations, particularly when the question of differences between denominations within a religion may arise. Pluralist Muslim women place positive value on diversity of Muslim practices and beliefs. Their conversations, rather than focus on the content of practices and beliefs, tend to center on their individual and social consequences. One of the pluralist Muslim women's key concerns is denouncing patriarchal practices in Muslim and non-Muslim settings they inhabit, while adamantly rejecting white, colonial feminism (Hamad 2020). They keenly draw from anti-patriarchal readings of the Qur'an and Islamic history but identify what they see as problematic religious interpretations and practices. With a keen eye for intersectional inequalities, they see challenging reductive and racist portrayals of Muslim women and men as essential. Therefore, our article taps into the wider discussion about the ecosystem of inexorably linked nonconformist, progressive, pluralist, and non-organized Muslim identities that share a number of concerns, including "striving to realize a just and pluralistic society through a critical engagement with Islam, a relentless pursuit of social justice, an emphasis on gender equality as a foundation of human rights, and a vision of religious and ethnic pluralism" (Safi 2003, p. 48) in contrast to exclusivist visions that posit Islam's epistemic and salvific supremacy. ${ }^{1}$

Some labels used in extant research for similar samples, such as "invisible Muslims", (Jeldtoft and Nielsen 2014, p. 5) or "silent Muslims" (Akbarzadeh and Roose 2011, p. 309) would be reductive, as they may inadvertently reproduce erasure of these Muslim women's voices as somehow not fully authentic or legitimate that we want pivot away from. We do not use Jeldtoft's term "non-organized Muslims", as our respondents inhabit a variety of contexts that do not fit into the organized/non-organized binary; many belong to religiously-framed Facebook groups and online worship communities. "Secular" and "moderate Muslims", political labels that operate in the imaginary "extremist Islam versus the secular West" binary, would flatten the complexity of religious expressions in our data. "Progressive Muslims", a term popular in academic discourse (Esack 2018; Safi 2003) is, from the perspective of our data's orientation, too imbued with Western-centric ideas of progress as linear development (McClintock 1992). "Nonconforming" Muslims used by Thompson (2020) is one of the labels closest to describing the population from which we draw our sample, but we decided against it given the centrality of collective worship for this group in Thompson's study.

\section{Visibility Bias in Sociological Study of Islam and Muslims}

Schielke $(2009,2010)$ argues against a visibility bias in research on Islam and Muslim that privileges two entities. The first is identities of people who consciously present themselves as pious Muslims, especially in circumstances where they intentionally perform these identities (such as mosques or study groups), thus neglecting the wider matrix of interests, commitments, and contexts in which these individuals function. The second entails essentialist discussions on the nature of Islam, removed from lived realities of Muslims. Schielke warns that this overemphasis on piety as Muslims' main motivation for action unwittingly privileges and reproduces Islamist movements' aspirations to cast Islam as the "supreme guideline of all fields of life". This approach, he argues, may lead to pervasive framing of Islam as a whole as a "perfectionist ethical project of self-discipline" (Shielke 2010, p. 2) in scholarship on Islam and Muslims. Instead, he posits the need for acknowledgement and exploration of the lives of "Muslims who-like most of humankindare sometimes but not always pious and who follow various moral aims and at times immoral ones ... If we want to account for the significance of Islam in people's lives, we have to account for it in this wider context" (Shielke 2010, pp. 2-3). 
Thus, we focus on expressions of Islam that are not necessarily oriented towards perfectionist religious ideals. We draw from Schielke (2009) who argues that the predominance of scholarship on individual revivalist/reformist Islam obscures the rich tapestry of Muslim identities of people of a Muslim background. Meanwhile, writings that privilege identities built around the notions of piety and ethical formation, as Marsden (2005, p. 261) argues, "are unable to confront the ways in which Muslims are called upon to face, explain and contend with inconsistencies and complexities in their attempts to live virtuous lives". At the very least, while these approaches may accurately describe realities of some Muslims, lived experiences of others (less commonly a focus of scholarly inquiry) are more appropriately accounted for using other lenses and paradigms.

Working from the premise that some "hypervisible" (Jeldtoft 2013, p. 23) forms, emanations, and traditions of Islam receive more media, policy and, consequently, research attention than others, we center in this article on lived, "everyday" Muslim practices-and the shifts in practices-among pluralist Muslim women during the COVID-19 pandemic. We agree with Ammerman (2007) and McGuire (2008) that these forms of religiosity deserve more scholarly attention, as in scholarship they have been long overshadowed by a large amount of research centering institutional religion and visible Muslim practices. In this study we account for those modes of religious engagement that do not fit the image of Islam as an idealized self-discipline project. Further, we wish to contribute to bridging a gap between the well-established macro-level study of political Islam and micro-level study of individual Islamic practice.

Similar to Jeldtoft (2011) and Aarvik (2021) who conducted research with "nonorganized" Muslims embracing "spiritualized" Islam in Germany and Norway, respectively, we explore the micropolitics of identity that are "not necessarily Islamic but are constitutive of people's daily lives" (Selby et al. 2018, p. 190), where distinctions between what is and is not religious are sometimes less salient. For example, taking a walk, reading a book, or participating in a protest may take on distinctly religious meaning for some, while for others, under certain circumstances, praying may lose any religious implication whatsoever. Taking as our cue Sedgwick's (2014, p. 281) observation that "Islam is only one influence among many and it is a classic methodological error to seek to explain everything that is done by a person or society that happens to be Muslim in terms of Islam", we acknowledge the fragmented, ambivalent, and often contradictory nature of everyday religious identities which may appear deficient or misguided from a perfectionist Islamic perspective oriented to piety (O'Brien 2018). This is exemplified by a statement made by Asma who outlined two modalities of her religious practice: "To be totally transparent, I really only pray/read Quran during Ramadan. Other ways that I observe Islam (modest clothing, eating halal, etc.) are not really an issue while at home" (Asma, 27, Sunni, Born Muslim, NewYork).

The visibility bias in the study of Muslim experiences continues to operate, to a large degree, in research conducted after the COVID-19 pandemic began. Studies tend to be clustered in the following groups: (1) at the interface of state/local authority policies and Muslim practices (Al-Astewani 2020; Bi 2020; Piwko 2021; Kostecki and Piwko 2021; Thurston 2020) (2) analyses of institutional religious responses (Kühle 2021) and media representations of Muslim communities during the pandemic (Poole and Williamson 2021; Rajan and Venkatraman 2021). The handful of studies conducted with Muslims tend to be quantitative, and conducted in Europe, MENA, and South Asia (Ali et al. 2020; Fekih-Romdhane and Cheour 2021; Jaspal et al. 2020; Ripon et al. 2020; Thomas and Barbato 2020). No studies, to our knowledge, have been published about American Muslims' experiences of COVID-19 at the time of publication. Our study, on the other hand, centers the perspectives of a subset of pluralist Muslims using qualitative methods.

\section{Methodology}

\subsection{Method}

The article is a result of a pilot study followed by a larger, interview-based project that is underway at the time of writing (Summer 2021). The pilot was conducted during spring 
2020, when many parts of the world were under lockdown due to the COVID-19 pandemic. Accordingly, the pilot methodology was devised so as to account for the limitations of the pandemic context of the research. As we were interested in self-reported qualitative shifts in religious practice among Muslim women during and after Ramadan 2020, we wanted to capture the multi-layered aspect of the phenomenon, in particular unexpected experiences, everyday practices, and discourses. We wanted to reach a relatively diverse group of participants while retaining a qualitative research focus.

With the above objectives in mind, we devised an open-ended questionnaire using Google Forms that we distributed online to individuals through our existing networks. Our "outsider" status hindered to some extent the recruitment process. As non-Muslim researchers we had to rely on the networks that were receptive to participating in the study and those consisted of our personal contacts and previous research participants.

As Chaudhary and Israel (2016, p. 141) argue, open-ended questions have the potential to "generate thick, rich and descriptive responses", at the same time offering ease of distribution, much needed in the lockdown conditions. In anticipation of a varying quality of responses, and the propensity of respondents to limit or avoid open-ended questions (Reja et al. 2003) we wrote in the questionnaire introduction: "If you are answering the below questions please keep in mind that this is a qualitative study, so the longer and more reflexive answer, the more useful it is for analysis". Furthermore, we tried to indicate our preference by formulating questions that asked for detailed descriptions. ${ }^{2}$ The questions focused on changes in religious practice brought by the lockdown (including the embracement of new elements), ways of coping with isolation, the use of Internet based groups and activities, family dynamics, and self-care practices.

\subsection{Sample}

We received thirty complete questionnaires in the first round (1-23 May 2020) and eight in the second phase of data collection (15 October-15 November 2020). Except a handful of monosyllabic answers, most responses were thoughtfully formulated, providing a wealth of data relevant for our purposes. Given that many respondents were recruited in religiously oriented social media groups, we found, similar to Schmidt et al. (2020, p. 27), that "motivated respondents and those high in ability provided higher quality responses". On the other hand, due to the indirect nature of the data collection, and potentially lower social-desirability bias, we managed to reach beyond the group that is the usual focus in research, namely those Muslims who present themselves as pious and committed and participate in the activities of religious groups and organizations.

For the purpose of this article, we removed four responses inconsistent with the definition of a pluralist Muslim described earlier. Out of the twenty-six respondents that remained, eleven identified as "born" Muslims, thirteen as converts, and two chose the "other" response. In terms of Islamic affiliation, twelve respondents self-identified as fully or mainly Sunni, three as fully or mainly Shi'a, eight described themselves as nondenominational, and three as feminist, progressive, or liberal. The open-ended responses allowed for flexibility in self-labeling, and the respondents often used qualifiers, rejecting essentialist typologies and divisions. Mariam, a "Floridian of Egyptian origins currently living in the Gulf" and born Muslim, wrote: "I'm Sunni. I would like to think I'm a Sunni who's more accepting of other traditions though". Others used modifiers and hyphenated identities: "vaguely Sunni", "loosely Sunni", "Sufi-Sunni", "Su-Shi” (Sunni-Shi'a). In the second round, two respondents identified as "born Muslims", and six as converts. In the first round, sixteen participants were located in the United States. Four were located in the United Kingdom, and one in each of the following countries or territories: Australia, Mexico, New Zealand, Occupied Palestinian Territory, Puerto Rico, and an undisclosed "Gulf State". In the second round, all eight respondents were located in the United States. Age range in both rounds was $27-58$, and mean age was 35 . Only one respondent completed both surveys. 
Both authors had studied-independently or in collaboration-various aspects of Islamic practices for over a decade. Our focus on the COVID-19 pandemic-induced changes in Muslim religious and/or spiritual practice is a natural extension of this interest in social realities which extend beyond our own. Although on a very general level, we were impacted by the global pandemic in similar ways, we do not share ethnic or religious identities with our participants. While our non-membership in the group under study does not necessarily create privileged access to participants or knowledge (Siraj 2012), it affords us a certain critical distance (Giametta 2018). Throughout the process of data collection and analysis, we considered the impact of our positionality-as non-Muslim, White, Polish, secular women-on the results. We are aware of the risks of misrepresenting Muslim women and communities at large, especially in the current social milieu imbued with Islamophobia.

\subsection{Analysis}

We read the responses multiple times before inductively identifying descriptive and analytic codes (for example, "solitude", "alienation", "shift to online", "decrease in practice") to organize the data. Clarke and Braun (2017, p. 298) comment that "inductive approaches are particularly useful when exploring a new terrain", which makes them appropriate for this study in terms of both sample (understudied subsection of the Muslim population) and context (a pandemic that profoundly affected social life). Then, we developed a thematic map of the codes that represented codes, wider themes, and relationships between them. The themes provided a framework for organizing and reporting our analytic observations (Clarke and Braun 2017). Given the type of the sample, purposive, we do not make claims about representativeness of our findings across the population of pluralist Muslim women in any setting. Rather, we approach our findings as a basis for case-to-case transferability (Firestone 1993). This method is historically found in legal studies, where a judge may compare precedents to a current case based on four criteria: material facts, appropriateness, reason for the decision, and the generality of the decision. Where this is adapted to social sciences, it is the reader who makes the transfer.

We assigned pseudonyms to the respondents based on their racial/ethnic background. Across the article, we include full respondent descriptors (usually age, convert/born status, Islamic affiliation, and location, if provided) only next to the first mention of their pseudonym, leaving only pseudonyms next to subsequent mentions. As the respondents could opt out of disclosing their background to preserve their anonymity, some descriptors are more exhaustive than others. We preserved the original spelling of the responses.

\section{Results}

With mosques shuttered and community gatherings severely limited, the collective experience of in-person prayers and interactions became unavailable for most, and so, we wondered how Muslim women in the US and the UK would respond to this situation. In our data, we have identified four distinct narratives describing the 2020 Ramadan in lockdown experience. Three of them are variously oriented to new and old individual religious experiences: The first conveys enthusiastic embrace of social-distanced/individual practices; in contrast, the second describes a profound sense of loss and aberration that is impossible to overcome in spiritual ways. The third narrative in this group highlights that for some Muslims, the pandemic brought no changes, as they continued to be isolated from their communities due to a variety of reasons. The fourth narrative is different from the first three, as it is focused on an affirmation of a virtual communality often experienced online. These themes enable us to draw some conclusions, but it is important to note that the separation of narratives as presented in this article is purely for analytic purposes; respondents often mobilized multiple narratives in their responses, reflecting the complexity and internal contradictions of religious identities. 


\subsection{Embracing the New, Socially Distanced Everyday and Affirming Solitude}

This narrative illustrated positive outcomes of the social distancing practices, experienced by 16 women in our sample (in both survey iterations (see Supplementary Materials)). It highlights some tensions between individual and collective practice; solitary practice offers some new spiritual benefits.

The workings of subjectivization of religion (Versteeg and Roeland 2012) are called to attention, as the respondents narrate the power of individual prayer in how it brings out personal experience and emotion, as illustrated by the words of Una, a Sunni convert from Florida who stated: "I've discovered that I love to pray alone too, I love how personal it is and how I can tap deep into my emotions somewhere totally private". Her remark dovetails with first-person accounts of the effects of prayer cited in Williamson's (2018) research. The respondents often marveled at the sense of connection with God, as well as vulnerability and intimacy rendered by du'a (supplication prayer). All described a feeling of peace and contentment that displaced previous concern with problems such as personal failure, discontentment, loneliness, and various other troubles.

Janene, a Sunni convert from California, also embraced the solitude resulting from the lockdown: "[I'm] discovering the value of (relative) solitude. ... Days and nights are spent at home and less complicated. Less social in a good way. Less distraction and less stress. ... Less stress overall from having to go to dinner parties and have guests over". This sentiment was echoed by Malika, a born Muslim from Birmingham (U.K.): "I'm enjoying this time of isolation-if only there was no suffering from the COVID-19, I'd be happy to continue". Many women in our study were able to pray more frequently and spend more time on meditation during the Ramadan during the pandemic, compared to a typical Ramadan. Dina, a born Shi'a Muslim from Michigan, asserted: "[I'm doing] lots more prayers than normal around iftar time". For her, the loss of sociality this Ramadan was compensated by the frequency of prayer around iftar time, when Muslims break the fast usually in the company of others. In similar vein, Helen, a "just Muslim" convert from Southwest England summarized the pandemic, as "solace in isolation-all this time alone for meditation and reflection". The increase in intensity and frequency of religious practices was still palpable in the second round of data collection. "I have become more religious, partly because I have more time for it. Plus, I needed something to help reassure me and help my anxiety", stated Anika, a convert to Shi'a Islam from the Washington, D.C. suburbs. Maya, a born Sunni woman from California, spoke about the lasting improvement in the quality of her religious practice: "I think that there is more focus on being deliberate and timely about the daily prayers".

Approached from the outside of "a single package of beliefs and practices of an official religion" (McGuire 2008, p. 11), lived religion encompasses some embodied practices that do not appear to be religious, and yet are vital for cultivation of a religious identity. Quotations in this section illustrate how the respondents reshape traditional religious practices in "highly individualistic, inclusive and pragmatic ways" (Jeldtoft 2011, p. 1141). In the following extract, Chanda discusses creating a bricolage of elements that traditionally might be considered as discrete: religious practice (prayer) and, variously, environmentally conscious behavior (giving up buying plastic) and emotional labor for her community (making uplifting posts). Her stance is a particularly poignant example of reconfigured religiosity:

I am using this time to reflect on my personal practice of islam. I can't fast (health reasons), so I am focusing on prayer and reflection. I also choose a new practice each year (couple of years ago I gave up all disposable plastic). This year I am focusing on lifting up my community.

(Chanda, Born Muslim, Sufi-Sunni Kashmiri American from upstate NY)

Private religion and spirituality emphasize the role of autonomy and personal experience, rather than traditional religious institutions and collectivities (Bellah 1985; Heelas and Woodhead 2005). Here, Khadijeh links quietness and solitude with increased spiritual valence of Ramadan: 
Part of me does think that Ramadan is meant to be much more quiet than the way most of the community participates in it, and I think being under lockdown kind of forces that [spiritual] aspect of Ramadan to be much more prominent. Because I've been able to create a schedule for myself more easily, I'm more able to wake up early to meditate or sign off of work earlier in the evening to rest.

\section{(Khadijeh, Born Muslim, Shi'i Ismaili, Chicago)}

Khadijeh's statement connects the lived religion and self-care perspectives, thus reinforcing a holistic approach to a spiritually charged reflexive project of self. As such, her statement challenges the distinctions between traditional and modern in the individual quest for self-improvement. The focus on interiority and appreciation of solitude highlights her somewhat critical approach to the normative practice of collective Ramadan celebration. Ameerah, a convert from Pennsylvania, described the effort inherent in practicing without the support of collective gatherings:

I realized if I wanted to feel a stronger spirituality, I have to practice what I know, and the only new thing would be that it takes more strength to do it without the motivation that comes with gathering with people that encourage you religiously. I miss that.

Although her statement points to some difficulties, it also implies a sense of strength drawn from solitary practice. A focus on positive thinking and positive practice provides the means of controlling and improving the self. The virtues to be achieved are formulated in manifold ways and include self-motivation, self-accountability, self-improvement (for oneself and others), self-acceptance/love that underpin the sense of identity and wellbeing. "[This Ramadan I am trying to cultivate] self-motivation and self-accountability. Although not connected with Islam they help me to do ibadah [worship] at home", stated Gina, a Sunni convert from Birmingham, UK. Quiyana (convert, mix of Sufi and Salafi Islam), foregrounded the notion of self-acceptance by stating: "I'm just trying to embrace the natural abilities Allah ta'ala [Allah Almighty] gave me without shame or guilt". Similarly, Alana highlighted a self-improvement goal:

I found out that the right religion is the one that makes you be a better person for yourself and others. And that sometimes Allah relieves you of toxic people that you love and it's for your own good. I am trying to find the better version of me... a stronger me.

(Alana, convert, Just Muslim, Puerto Rico)

Alana's reflection on Islam making her a better person not just for herself but for others as well demonstrates a particular kind of sociality, a religious orientation to the collectivity that points to intersecting (and gendered) obligations, expectations and master narratives that challenge the view of privatized religion as disconnected from community.

The self-project goes beyond the spiritual, internal realm and involves also the embodied self. We asked our respondents about their self-care practices during the lockdown. Some women reported devoting more time to self-care. "[My routines] have been better, actually. I used to feel guilty taking time for self-care, but with the pandemic and the fact that I live alone and don't have any plans to keep means that I can take care of myself more and not feel guilty", stated Aliya, a convert to Sunni Islam from upstate New York. Similarly, Vicky, a convert from Michigan observed: "I actually think I am taking more self care ... than usual, because it's at a forefront and my mental health isn't exactly $100 \%$ stable it is definitely a necessary part of this lockdown for me".

The responses referenced healthy eating, achieving regular sleep patterns, exercising and attending to various beauty regimes. "I am eating healthier and have more time to cook and clean up. Eating less processed food and saving money. Have more time to look after me and pamper myself. Feeling less tired in the day", stated Helen, quoted earlier. Similarly, Felizia, a convert to Sunni Islam from Mexico, spoke about taking more care with food: "Well now I am exercising more and I am taking more care in not preparing high sugar meals for the family". Chanda noted: "[My routines have changed] Slightly, but 
not too much. I wake up early and go to bed early. Buffoonery by the country's president [at the time of data collection, Donald Trump] keeps me up sometimes, but I try not to listen to him". At least for some women, the change in self-care practices seems to a lasting effect of the changes brought by the pandemic. Maya reported in the second round of data collection:

Earlier in the year (beginning of COVID) I do think, however, that we have gotten more creative with our workout and gym routine, along with doing more yoga. I have also greatly enjoyed trying new dishes in the kitchen, and now for the first time have found cooking to be therapy. In addition, I started to take baths for the first time in my life [ . . . ] In the past several months, mainly due to workload, I have had very little systematic self-care practices, but have found NEW practices that I will begin to continue implementing on a regular basis once the workload reduces at the end of year.

In light of recent literature on religion and consumer culture, the divisions between what's strictly religious, strictly spiritual, and strictly secular have never appeared more contrived. Various transformative self-projects that entail self-care, self-acceptance, spiritual work, and ethical cultivation undertaken during the pandemic are inextricably bound with religious belief and practice. Kenney (2015) argues that the valorization of self-exploration and self-fulfillment facilitates blending of modern ideas and ethical practices rendered legitimate through association with tradition and fosters new understanding of what it means to be Muslim in modern world. Similarly, Gauthier et al.'s (2013) edited volume Religion in Consumer Society pulls together various case studies that demonstrate that selfrealization, along with freedom and choice, are all part of a modern-day zeitgeist that shapes religion into a lifestyle.

The data organized in this narrative speak to the way in which the notions of "expressive individuality" and "associated sociality" are not deemed mutually exclusive. There are subtle hints in the responses that the shift to solitude is a gentle pivot, rather than an adamant departure from collective practice. Una, quoted at the very beginning of this section, and in the article's title, said "I've discovered that I love to pray alone too", implying that she loved praying in a group before; Chanda's practice, while more individualized, was not entirely directed inward; while she emphasized personal aspects of her religiosity, she integrated it with a community orientation (making uplifting posts), which she was able to realize in a socially distanced way. Ameerah confessed she missed the "motivation that comes with gathering with people that encourage you religiously". These responses also highlight that developing a disposition for solitary practice is more effortless for some than others; Ameerah's ambiguous attitude to individual practice in particular echoes the protracted process of developing a religious disposition by Mahmood's participants (2005) who had to shape their bodies and minds into appreciation of certain practices through repeated practice. Intentionally reforming one's disposition to solitary practice could be interpreted as creation of a new religious habitus (Krotofil et al. 2021) - in this case, a "Covid habitus".

However, the emphasis on "positive value of subjective religious signification" that centers individual experience (Versteeg and Roeland 2012, p. 123) is not all-pervasive in our dataset. In the next section, we discuss the narrative of spiritual loss due to pandemic conditions.

\subsection{Alienation, Disconnection, and a Palpable Sense of Loss}

Nine respondents wrote about difficulties inherent in the lack of social interactions during Ramadan. As religious identities are dynamic and contextual, we are aware that the identities that emerge here are temporary in respondents' lives, necessarily framed by the new limitations and affordances of the pandemic. Additionally, the bulk of our data was collected during Ramadan, a holiday that traditionally prioritizes collective celebrations. In this narrative, Ramadan 2020 became a moment of crisis. In such a context, a particular 
identity of crisis identity of crisis (Peek 2005), whereby one's religious identity is affected by external circumstances and individual ways they negotiated, is an increasingly salient one.

For our respondents, staying at home all day for some meant a loss of events structuring the day with which religious practices were interwoven, demonstrating the integrative, dynamic nature of lived religion (Jeldtoft 2011). Many respondents had a deep sense of transition into abnormal reality and struggled to cope with it. Tara ("Other", Loosely Sunni, USA) said "Well, I'm terrible at praying when I'm home all day. I've tried reading the Study Quran but it's hard to concentrate without better segmentation of my day". Her experience was similar to that of Donna (Sunni-Shi'a, convert, Midwest USA), who bemoaned the loss of her old routine in which her bodily practice used to be firmly anchored: "I've tried doing better at praying, but I get very 'stuck' on the couch. It's easier to pray if I'm already up and moving between tasks, instead of doing all my work/class/homework in one spot that also happens to be my relaxing spot". In Tara's and Donna's cases, loss was framed as the loss of "segmentation of the day" and "movement" which had been influenced by non-religious activities previously conducted outside the home.

The palpable sense of loss of connection closed, for some, the possibility for a "full" Ramadan experience. The following quotations, however, show that some respondents reflect on alternative modalities of it. In doing so, they reflect, analyze and open up the possibility for reconfiguration of the experience that was defined by routines and schedules.

Several women describe how their Ramadan practice had been rooted in communal prayer and celebration, the loss of which impacted their motivation to pray alone:

It's been a little hard because Ramadan is so different this year-communal iftars and taraweeh, which I associate with a normal Ramadan are no longer normal. I've always prayed taraweeh communally, which has helped motivate me to pray more additional prayers.

(Maryam, born Muslim, Sunni, Florida/"The Gulf")

Other women observed: “It's been tough; I'm used to attending my place of prayer about twice a week and having community events on top of that, so it has been quite a jarring shift" (Khadijeh); "This is my first Ramadan as a Muslim and I was really looking forward to spending time with my community. I am struggling a bit with being alone but trying to find the blessing in all situations alhamdulillah" (Aliya).

Hafsa (born Muslim, Sunni Palestinian, Jerusalem) describes a profound sense of disorientation due to the loss of sociality during the 2020 Ramadan:

It has been a struggle and disbelief of how this Ramadan has been. It just doesn't really feel like Ramadan. Our annual routines and schedules that we have set up months prior are not in place and it has rethinking everything we want to do and if it is possible during this time of quarantine.

Many participants talk about faith (imaan) fluctuations that they associate with less rigorous practice. In the second round of the survey, Quiyana, who leads an online mosque, disclosed: "my Imaan has dropped a lot unfortunately".

While this narrative of loss revolved around inability to cope with loneliness and, sometimes, associated mental health issues, one respondent described a situation that highlighted spiritual struggles related to loss of privacy through being stranded in an overcrowded family setting. As Afrah (Born Muslim, Sunni Hanafi, Chicago) explained, feelings of frustration and anger about her entrapment with a large family pod stand in the way of a full Ramadan experience.

It's been rough since Ramadan is in quarantine. We've been stuck with each other for two months which enhances anger and frustration even in Ramadan. My cousin and her husband are also living with us which makes the house more full and more frustrating. I wish we had some space and distance. I feel like I've been irritated and angry a lot this Ramadan and I wish I wasn't...I am surrounded by Indian Muslims all around who all happen to be family. So I'm surrounded by about 100 relatives which has its pros but many cons. 
Here, we see the other side of the lockdown coin. Solitude, so relished by others, emerges as an unattainable coping strategy. Instead, Afrah and her family are exposed to overcrowding in the home, considered in psychology and counselling to be a chronic stressor that often leads to family conflict (Shaw and Emery 1987). Family rituals involve affective and symbolic communication (Wolin and Bennett 1984) featuring disruptive as well as supportive elements (Fiese 2006). Thus, Afrah is unable to achieve inner peace, a sense of generosity or compassion that define Ramadan for her.

These responses, however, while illustrating the sense of loss in relation to collective practice, as well as established, pre-pandemic routines, do not easily fit into either the "mosqued/unmosqued" or "individual/collective" binaries. For the respondents, collective religious practice does not necessarily denote institutionalized worship. In our dataset, we did not encounter responses that would explicitly express nostalgia for attending mosque (masjid); rather, they imply the loss of community that used to structure religious practice and routines pre-pandemic. It is not surprising, given many women's ambivalent attitude to entering formal religious settings, as illustrated in the next section.

\subsection{Disenfranchisement}

This narrative was an outlier; in contrast to the other three, it was about change in religious practices caused by the pandemic restrictions. It was mobilized by a small group of three respondents who indicated that they had always lacked a community connection and they continued to feel disconnected in 2020, regardless of the pandemic. The first respondent referenced gender inequalities in mainstream mosque settings as the reason for her disenfranchisement:

Not much has changed as I am generally not attending the mosque due to feeling constrained there as a second class citizen. My husband goes every day in Ramadan for taraweeh and I am a little relieved he's not attempting it at home because then I'd feel guilty for not joining him.

(Selina, Born Muslim, Sunni, Texas)

Her disaffiliation from the formal religious community did not appear to deter her from other, de-institutionalized forms of religious practice, however. She simultaneously described engagement in family Ramadan practices: "The whole family tunes into the live Noor Kids Ramadan program". Selina also reflected that "duas [supplications] read off a mobile phone can be compelling", and hinted that she fasted, suggesting that the lack of religious practice beyond her immediate family did not hinder her commitment.

The picture painted by Bana's responses (born Muslim, Tennessee) was altogether different. She commented: "I was isolated from the Muslim community before [the pandemic], so I'm fine with it". Her account suggested that while she was used to being disenfranchised, she was overwhelmed by the conflicting time demands of motherhood and education: "Since I am a full time student, I am stressed about not having time to focus on any one thing...I get no time for self-care anymore". To our question regarding spiritual practices, she simply responded: "I found out that I'm not a very spiritual person". Her case suggests that for some Muslims, religion is not a place from which one can draw resilience or support. And yet, they may still identify as Muslim (which Bana explicitly did as she selected the "born-Muslim" characteristic in our questionnaire). Unlike Fadil's (2009) participants who framed non-engagement in religious practices during Ramadan as a political act, an explicit choice not to participate in religious practice, there is a sense that for Bana, religious practices of any kind do not even feature on her register. Experiences of Bana and other non-practicing Muslims are usually invisible, and yet, an indisputable element of the bricolage of Muslim experience (Shielke 2010).

While some respondents orient themselves in different ways to individual religious practice, others narrate meaningful ways in which their experiences remain collective, if transformed. Importantly, this transformed collectivity highlights the continued, albeit more subtle and implicit workings of external religious authority. 


\subsection{Reshaped Religious Collectivities}

In contrast to many respondents who narrated their recent reconfiguration of religious and social practice due to isolation, with varying degrees of ambivalence about formal, institutional religious worship, some respondents who linked their experiences to being converts, transgender, queer, disabled, or feminist reported having been "unmosqued" for a long time. For those respondents (who constituted approximately one-third of the sample), the profound sense of isolation before the pandemic gave way to actively coming together online. The new situation appears to have acted as a catalyst.

While there is an increase in progressive, women-led, LGBT-affirming mosques, these tend to be founded in larger cities such as Chicago, LA, Toronto, Berlin, or London (Carvajal 2019; Thompson 2020). For those living in smaller cities or rural areas, these institutions are less accessible. The lockdown has certainly exposed the challenges experienced by this diverse group as people everywhere suddenly started experiencing alienation (Flaskerud 2021).

The rise in collective worship online can be explained by the argument that a sense of common religious dedication does tend to surge during and immediately after major external crises (Demerath and Farnsley 2007). In our study, the increased sense of belonging and redefinition of the community of faith was most remarkable among those Muslims who experienced exclusion in the mainstream community:

Right before the pandemic started, I had made niyyah (intention) to attend Jummah prayer each week. Obviously this didn't happen. As Ramadan approached, I had inspiration from Allah subhana wa ta'ala (Allah almighty) and I created a virtual masjid (mosque)-Daar ul-Gharib (Home of the Stranger)-for Queer Muslims (mostly femme and non-binary), who already are generally isolated in the larger Muslim community. Alhamdulillah (praise be to God) this has helped us all have a home even if we can't congregate physically! We hold congregational prayer daily, as well as Quran reading and classes.

(Quiyana)

Without a Muslim family, converts rely much more on the community and communal events in mosques and cultural centers (Linskens 2020). Some of our converted respondents living side by side with communities of born Muslims also reported being made to feel unwelcome.

Unfortunately I've never had any sort of physical community to be a part of because I'm Transgender. So my coping strategy of basically connecting with Muslims socially online is my only means of really connecting to the Muslim Community.

(Paula, Sunni, New Zealand)

Physical spaces such as mosques are extremely misogynist so I'm not involved with them anyway. Other events in progressive spaces are few and far between and often I can't attend them due to disability. So now that everything is online, it's great.

(Wazeera, Born Muslim, Feminist Islam)

While acknowledging alienation and frustration with feeling excluded from the "mosqued" Muslim community, Paula and Wazeera actively overcome the excluded status and engage in building a supportive, like-minded community online.

Our data evidences the existence of various networks and micro-networks within the "cyber-Islamic environments" (Bunt 2003, passim). In our research, we observed reconfigurations of practice, often, but not always, coupled with production of radical religious knowledges which cause "paradigmatic shifts" at the grassroots level. Even practices that may not immediately strike one as radical, such as finding an online prayer group or listening to a lecture, often involve exercising religious agency, as an individual 
has to make a string of decisions with which content they wish to engage, to what degree, and in what ways.

Notably, many of our respondents did not simply consume digital religious content; they produced it and co-created their own collectivities. However, almost all respondents, regardless of their ideological stance, expressed appreciation of online affordances in the context of doing religion in 2020. A few of them noted with surprise that doing religion online is productive in terms of religious practice: "I have been able to find a prayer group online that's been really supportive of me and has helped me learn how to pray better". (Paula); "I am listening to lectures that I normally didn't listen to. They have enlightened me to so many new things". (Afrah) Wazeera stated that for her, online religious and social experience was superior to in-person one:

Maybe it's just that in person events result in mind-numbing small talk whereas online ones lead to more meaningful convos including spiritually focused ones.

And the online convos are a bit more curated with like minded ppl.

The ability to be selective in regard to one's conversation partners is emblematic of online safe spaces, usually theorized in relation to minoritized sexual, gender, and racial identities (Lucero 2017; Clark-Parsons 2018). Wazeera, an administrator of a feminist Muslim group on Facebook, is responsible for maintaining symbolic boundaries that delineate the safe online space she inhabits. Having initiated multiple collaborative religious events online prior to the pandemic, and created a large network of like-minded individuals, she was probably better prepared for the pandemic reality than many other respondents.

Challenging scholarship that claims that individualization and privatization of religion would lead to fragmentation and chaos in religious belief and practice, Gauthier et al. (2013, p. 15) posit, drawing from Hervieu-Léger's (2000) work, that while the latter may be disconnected from the "webs of meaning in which they were previously inscribed, they are reintegrated into new globalized networks of consumer culture in which expressive individuality and associated sociality thrives".

This observation applies in particular to the online mosque created by Quiyana. While catering to a different segment of Musims in a different space than traditional mosques, Quiyana draws from the web of meaning in which religious practices were originally inscribed, that is the name for her online space (a mosque, rather than a group or a forum), and the order and content of prayers, the preaching of a sermon ( $k h u t b a)$, and finally, the use of Arabic by Quiyana. She integrates different systems of signification which give a subjective meaning to her and her attendees' own experiences (Hervieu-Léger 2003, p. 161) while, simultaneously, creating preferred communal affiliations. Wazeera, with collaborators from her group, which does not operate as an online mosque, rather an informal community, invited other women to record their Qur'an recitations or calls to prayer, which were subsequently posted online on a dedicated website. She described this initiative as a reclamation of these practices by women who are sometimes prevented from using their voices, believed by some traditionalists to be immodest, in public. The online communities created by Quiyana and Wazeera encapsulate the process identified by Hervieu-Léger (2003, p. 167):

The more people "cobble together" a small-scale system of belief adapted to their own needs, the more they aspire to share this experience with others who share in the same type of spiritual aspiration. This seeming contradiction accords with the intrinsic limits of the self-validation of faith. For individuals to stabilize the meanings they produce to give significance to their daily experience, they must find outside of themselves a confirmation of the validity of these meanings.

Quiyana articulated particularly strongly that the pandemic conditions led her to adapt codes of meanings anchored in traditional Muslim institutions to establish a shared universe of meaning through mutual exchange with like-minded individuals, that is, participants in the online mosque. Hervieu-Léger (2000, p. 96) explains that 
the purpose of such support groups is precisely that they provide a forum for saying: 'Your problem is my problem; the answer you come up with is my answer too'. The more painful or complex the problem, the more it involves extreme situations, the more vital the exchange. Sickness, calamity, failure, death-once such scourges are no longer resigned to as an inevitable part of human life-are necessarily seen as appalling injustices and reversals to self-realization... At such times resources that offer mutual comfort and support constitute the only antidote to the often unbearable sense of isolation of having to stand on one's own. They constitute an elementary form of what we have pointed to as a form of social recognition of individual meaning.

This very social recognition of individual meaning in the pandemic conditions may have crystallized, for some, as a particular religious identity with an associated habitus that imbues solitary, socially distanced practice, with new meaning and striving for new forms of sociality, such as online gathering in various forms. Peek (2005) has argued that 9/11, a crisis event steeped in cultural politics reaching well beyond the US, led to the formation of identities of crisis among American and European Muslims. For many, the religious identity has become much more central for their personal and social selves at that time, as Islam came under intense scrutiny and Muslims experienced heightened hostility. Although the ongoing pandemic is a very different crisis than $9 / 11$, we argue that it has contributed to the emergence of a particular identity of crisis, shaped variously by social distancing, changes in work mode such as remote work, riskier in-person work, loss of employment, overall stress, and, frequently, a reconfigured mode of religious comportment that relies strongly on individual and online collective practices.

\section{Discussion}

By engaging a purposive sample of pluralist Muslim women, we have taken stock of developments that occur outside of the frequently engaged population of "piety-oriented" Muslims, preserving the gendered aspect of religious and religious-adjacent experiences. This has allowed us to identify the ways in which pluralist Muslim are coping with the challenges of the pandemic, which for many, has enforced renegotiation of religious practice. By adopting such a focus, this article adds to the small but growing body of literature on the ecology of broadly understood pluralist Islam that has the potential to address the methodological neglect of Muslim populations that cannot be categorized as visibly pious in social scientific study of Islam. ${ }^{3}$ In addition, by focusing on pluralist Islam as a less visible and thus less represented mode of living and doing Islam, we wish to complicate the term "Muslim" as an ascribed category of practice in Western discourse (Mansouri 2020). The hyphenated preferred identifications used by the respondents (such as "Sunni Palestinian", "Kashimiri American", "loosely Sunni", "queer Muslim") clearly demonstrate the significance of intersecting religious, political, ethnic, and biographical identities. The wish to represent this diversity, and to avoid the reductive tendency to portray Islam as reified, static, and homogeneous remains, however, in tension with the recognition that in a hostile political climate, especially since $9 / 11$, individuals with a Muslim faith background increasingly embrace the Muslim identity to "revalorize what has become devalorized" (Brubaker 2013, p. 3).

As our sample was largely self-selected/purposive, we cannot generalize from it to the target population, yet we can use the findings to formulate more sophisticated conclusions about impact of COVID-19 on practices of Muslims more widely. Our data simultaneously highlights the parallel, longstanding trends in the study of lived religion (subjectivation, holistic approaches, refashioned collectivities, fractured religious identity, departure from dogmatic belief) and the degree to which the COVID-19 pandemic has transformed religious experience for some Muslims. We argue that the pandemic conditions have effectively boosted the intensity of processes that underpin religious modernity, in particular individuality (through enforced social distancing/isolation) with its associated sociality (as a subsequent response to the individual experiences). 
Further, our article highlights that the usefulness of "mosqued" /"unmosqued" typologies in the context of the pluralist Muslim sample is limited; in their practice, mosques are often replaced by reconfigured communities, or recreated online as places of building relationships across, and through, difference (Eck 2001). Similarly, it appears that the "born Muslim" /"convert/revert" status differential loses salience among pluralist Muslims, compared to "visibly pious" Muslims; the notion of authenticity of one"s "Muslimness", key for converts to more mainstream versions of Islam (Moosavi 2012) is supplanted by "encounters of commitments" (Eck 2001, p. 72) and active seeking of understanding across lines of difference (Eck 2007).

Ramadan emerges in the analyzed responses as the time of year when "technologies of self" (Foucault 1988, p. 18) are applied with particular intensity, geared to "permit individuals to effect by their own means or with the help of others a certain number of operations on their own bodies and souls, thoughts, conduct, and way of being, so as to transform themselves in order to attain a certain state of happiness, purity, wisdom, perfection, or immortality". The themes of healing and wellbeing, vital in the consumerist culture, are thus identified across religious traditions, including Islam. Religiosity is often studied quantitatively as a potential predictor of wellbeing (Dahlin et al. 2021), with the relationship identified as the strongest in Muslims (Dilmaghani 2018), including during the current pandemic (Thomas and Barbato 2020). The patterns related to fluctuations of religiosity levels during Ramadan 2020 and afterwards identified in our study suggest that it would be apt to also study the opposite relationship, in which wellbeing is a predictor of religiosity.

Our study provides support for the consideration of the "limitations of practical circumstances" postulated by Schielke (2009, p. S25). In the case presented here, the outbreak of the COVID-19 pandemic and the resultant restrictions represent exceptional practical circumstances.

The moral universe in which Ramadan morality is embedded is characterized by a profound ambivalence that is not only a coincidental result of circumstances but actually provides the foundation of situational moral action and an ethical subjectivity that is based on a coexistence of various motivations, aims, and identities that can and often do conflict but do not constitute exclusive opposites.

\section{(Schielke 2009, p. S29)}

There is, however, some ambivalence inherent in Ramadan celebration. This ambivalence is echoed in the accounts of pluralist Muslim women's experiences during the Ramadan in lockdown that seem to demonstrate that the Ramadan time morality is also contextual. Our data demonstrates that the rigor, usually approached with a degree of flexibility to accommodate the special needs of the sick, nursing, and menstruating women, as well as travelers, is extended in the exceptional circumstances of the pandemic; suddenly everyone occupies the "exceptional" category, as the entire human population is subject to infection prevention and control measures (lockdown, quarantine, restricted travel, social distancing), that operate as society-wide stressors.

Being deprived of the possibility to gather in collective ritual and related communitybased activities came as a joyful discovery for some, while to others, it represented unambiguous impoverishment of the religious experience. On the whole, it appears that the changes in social interaction have led to a re-evaluation of salient aspects of the religious identity for many surveyed women; for others, it highlighted or aggravated longstanding modalities of exclusion. Our data highlights pluralization of religious experience; however, the durability of these shifts remains unknown. Believers could take these lessons about community building and fundamentally transform traditional religious spaces, especially building on the wave of new all-inclusive mosques in Western Europe and North America (Nyhagen 2019; Thompson 2020). It is also likely that they continue to worship online, or return to the original, pre-pandemic modes of engagement once the pandemic is over.

The limitations of this article-chiefly related to the small dataset, and the specific sample and research method that were to a large extent dictated by the pandemic conditions- 
offer some avenues for future study that would illuminate our findings from other angles. First, collecting survey responses from a larger sample, more representative of Muslims in the United States and the United Kingdom, and other countries where our respondents originate would indicate if the trends we identified are more ubiquitous. Second, an online survey, like all other online research methods, carries an inherent bias of reaching younger, wealthier, and internet-savvy respondents due to the persistent digital gap (Vogels 2021). The questionnaire could be distributed physically to reach other sections of the population. Third, following up with a method that allows probing and a more interactive data collection process, such as individual or focus group interviews would increase explanatory power of the argument we offer. Finally, as the pandemic conditions are simultaneously the context and limiting factor for the study, repeating the study after the pandemic ends may indicate how context-specific or permanent our findings are.

Supplementary Materials: The following are available online at https:/ / www.mdpi.com/article/10

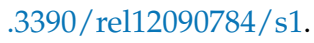

Author Contributions: Conceptualization: A.P. and J.K.; methodology: A.P. and J.K.; formal analysis A.P. and J.K.; resources: A.P. and J.K.; writing (original draft preparation): A.P. and J.K.; writing (review and editing): A.P. and J.K.; supervision: A.P. and J.K. Both authors have read and agreed to the published version of the manuscript. Both authors have read and agreed to the published version of the manuscript.

Funding: This research received no external funding.

Institutional Review Board Statement: Not applicable.

Informed Consent Statement: Informed consent was obtained from all subjects involved in the study.

Data Availability Statement: The data presented in this study are not publicly available due to confidentiality requirements.

Acknowledgments: Findings discussed in this article were presented as part of the "COVID-19 and Muslim Religiosity" webinar series at Ali Vural Ak Center for Global Islamic Studies at the George Mason University in November 2020. We thank the organizers and attendees for the constructive discussion. Also, we thank Katrina Daly Thompson and Michael C. W. Woolf for their comments on the first draft of this article. The anonymous review reports have helped to clarify our argument. Finally, we are immensely grateful to respondents who completed the questionnaires.

Conflicts of Interest: The authors declare no conflict of interest.

\section{Notes}

1 Even though the terminology we employ may somewhat reflect the exclusivist-inclusivist-pluralist distinctions of the threefold paradigm of interfaith approaches (Thompson 2017), they do not neatly map onto our discussion, given their Christian-centric origin. The impact of colonial conquests in Muslim-majority societies shaped Muslim theological perspectives on interfaith issues differently. Instead, we drew from Hefner's (2000, p. 12) use of “civil pluralist Muslim" in the context of Indonesia's governance. It is the main context in the social scientific study of Islam in which the term "pluralist" appears.

2 We marked all questions as "required", technically preventing participants from skipping questions. Anticipating that some questions might be irrelevant to some women's experiences, we suggested that they input N/A when appropriate.

3 It is worth noting that while in social scientific study of Islam and Muslims, the main focus is on visibly pious Muslims, in the world of social justice activism, this very category remains marginalized, as the visibly pious, along with recent immigrants, Muslims with non-standard accents, and Muslims with criminal records are not engaged in anti-Islamophobia initiatives in the United States (Islam 2018). This discrepancy reflects an insidious Orientalist logic that situates the visibly pious as an interesting (exotic?) object of study that is simultaneously "too religious" to make a worthy partner in anti-racist struggle, even if such struggle is explicitly oriented to the Muslim religious identity. 


\section{References}

Aarvik, Signe. 2021. 'Spiritualized Islam': Reconfigurations of Islamic Dogma Among Young Non-Organized Muslims in Norway. Islam and Christian-Muslim Relations 32: 81-96. [CrossRef]

Akbarzadeh, Shahram, and Joshua M. Roose. 2011. Muslims, Multiculturalism and the Question of the Silent Majority. Journal of Muslim Minority Affairs 31: 309-25. [CrossRef]

Al-Astewani, Amin. 2020. To Open or Close? COVID-19, Mosques and the Role of Religious Authority within the British Muslim Community: A Socio-Legal Analysis. Religions 12: 11. [CrossRef]

Ali, Amjad, Mumtaz Ahmed, and Nazia Hassan. 2020. Socioeconomic impact of COVID-19 pandemic: Evidence from rural mountain community in Pakistan. Journal of Public Affairs, e2355. [CrossRef] [PubMed]

Amini, Mostafa, and Anwar Ouassini. 2020. Divergent Islamic perspectives: Yoga through the lens of societal custom. Culture and Religion 21: 199-214. [CrossRef]

Ammerman, Nancy T., ed. 2007. Everyday Religion: Observing Modern Religious Lives. Oxford: Oxford University Press.

Bellah, Robert N., ed. 1985. Habits of the Heart: Individualism and Commitment in American Life. Berkeley: University of California Press.

Bi, Suriyyah. 2020. Racialisation of Rescuehood: Contextualising British Muslims Stuck Abroad during COVID-19 Pandemic. Journal of British Muslim Studies. Available online: https:/ / www.britishmuslimstudies.com/post/racialisation-of-rescuehoodcontextualising-british-muslims-stuck-abroad-during-covid-19-pandemic (accessed on 14 September 2021).

Brubaker, Rogers. 2013. Categories of analysis and categories of practice: A note on the study of Muslims in European countries of immigration. Ethnic and Racial Studies 36: 1-8. [CrossRef]

Bunt, Gary R. 2003. Islam in the Digital Age: E-Jihad, Online Fatwas, and Cyber Islamic Environments. Critical Studies on Islam. London and Sterling: Pluto Press.

Carvajal, Doreen. 2019. Finding a Place in Women's Mosques. The New York Times, March 8.

Chaudhary, Anil, and Glenn Israel. 2016. Assessing the Influence of Importance Prompt and Box Size on Response to Open-ended Questions in Mixed Mode Surveys: Evidence on Response Rate and Response Quality. Journal of Rural Social Sciences 31: 139-59.

Clark-Parsons, Rosemary. 2018. Building a digital Girl Army: The cultivation of feminist safe spaces online. New Media E Society 20: 2125-44. [CrossRef]

Clarke, Victoria, and Virginia Braun. 2017. Thematic analysis. The Journal ofPositive Psychology 12: 297-98. [CrossRef]

Dahlin, Moa Kindstrom, Oscar Larsson, and Anneli Winell, eds. 2021. Religion, Migration, and Existential Wellbeing. New York: Routledge.

Demerath, N. Jay, and Arthur E. Farnsley. 2007. Congregations Resurgent. In The SAGE Handbook of the Sociology of Religion. Edited by James A Beckford and N. Jay Demerath. London: Sage, pp. 193-204.

Dilmaghani, Maryam. 2018. Religiosity and Subjective Wellbeing in Canada. Journal of Happiness Studies 19: 629-47. [CrossRef]

Eck, Diana L. 2001. A New Religious America: How a "Christian Country" Has Now Become the World's Most Religiously Diverse Nation, 1st ed. San Francisco: HarperSanFrancisco.

Eck, Diana L. 2007. Prospects for Pluralism: Voice and Vision in the Study of Religion. Journal of the American Academy of Religion 75: 743-76. [CrossRef]

Esack, Farid. 2018. Progressive Islam-A Rose by Any Name? American Soft Power in the War for the Hearts and Minds of Muslims. ReOrient 4: 78. [CrossRef]

Fadil, Nadia. 2009. Managing affects and sensibilities: The case of not-handshaking and not-fasting: Managing Affects and Sensibilities. Social Anthropology 17: 439-54. [CrossRef]

Fekih-Romdhane, Feten, and Majda Cheour. 2021. Psychological Distress Among a Tunisian Community Sample During the COVID-19 Pandemic: Correlations with Religious Coping. Journal of Religion and Health 60: 1446-61. [CrossRef] [PubMed]

Fiese, Barbara H. 2006. Family Routines and Rituals. Current Perspectives in Psychology. New Haven: Yale University Press.

Firestone, William A. 1993. Alternative Arguments for Generalizing From Data as Applied to Qualitative Research. Educational Researcher 22: 16-23. [CrossRef]

Flaskerud, Jacquelyn H. 2021. Stress in the Age of COVID-19. Issues in Mental Health Nursing 42: 99-102. [CrossRef] [PubMed]

Foucault, Michel. 1988. The Care of the Self. London: Allen Lane.

Gauthier, François, Tuomas Martikainen, and Linda Woodhead. 2013. Introduction: Consumerism as the Ethos of Consumerist Society. In Religion in Consumer Society: Brands, Consumers and Markets. Edited by François Gauthier and Tuomas Martikainen. Burlington: Ashgate.

Giametta, Calogero. 2018. Reorienting Participation, Distance and Positionality: Ethnographic Encounters with Gender and Sexual Minority Migrants. Sexualities 21: 868-82. [CrossRef]

Haddad, Yvonne Yazbeck, Jane I. Smith, and Kathleen M. Moore. 2006. Muslim Women in America: The Challenge of Islamic Identity Today. New York: Oxford University Press.

Hamad, Ruby. 2020. White Tears/Brown Scars: How White Feminism Betrays Women of Color. Berkeley: Catapult.

Heelas, Christopher, and Linda Woodhead, eds. 2005. The Spiritual Revolution: Why Religion Is Giving Way to Spirituality. Malden: Blackwell Pub.

Hefner, Robert. 2000. Civil Islam: Muslims and Democratization in Indonesia. Princeton: Princeton University Press.

Hervieu-Léger, Danièle. 2000. Religion as a Chain of Memory. New Brunswick: Rutgers University Press. 
Hervieu-Léger, Danièle. 2003. Individualism, the Validation of Faith, and the Social Nature of Religion in Modernity. In The Blackwell Companion to Sociology of Religion. Malden: Blackwell Publishing Ltd., pp. 161-75.

Hussain, Nausheen, and Javonte Anderson. 2020. For Chicago-area Muslims without traditional mosque access, a remote Ramadan isn't a new concept. The Chicago Tribune, April 24. Available online: https://www.chicagotribune.com/coronavirus/ct-coronaviruschicago-ramadan-women-20200424-mhufcude3zbj7j145evobjit6q-story.html (accessed on 14 September 2021).

Islam, Namira. 2018. Soft Islamophobia. Religions 9: 280-96. [CrossRef]

Jaspal, Rusi, Barbara Lopes, and Pedro Lopes. 2020. Fear, social isolation and compulsive buying in response to COVID-19 in a religiously diverse UK sample. Mental Health, Religion $\mathcal{E}$ Culture 23: 427-42. [CrossRef]

Jeldtoft, Nadia. 2011. Lived Islam: Religious identity with ‘non-organized' Muslim minorities. Ethnic and Racial Studies 34: 1134-51. [CrossRef]

Jeldtoft, Nadia. 2013. The Hypervisibility of Islam. In Everyday Lived Islam in Europe. Edited by Nathal M. Dessing, Nadia Jeldtoft and Linda Woodhead. London: Routledge, pp. 23-38.

Jeldtoft, Nadia, and Jørgen S. Nielsen. 2014. Introduction: Methods and Contexts in the Study of Muslim Minorities. In Methods and Contexts in the Study of Muslim Minorities: Visible and Invisible Muslims. Edited by Nadia Jeldtoft and Jørgen S. Nielsen. London: Routledge, pp. 1-10.

Kenney, Jeffrey T. 2015. Selling Success, Nurturing the Self: Self-Help Literature, Capitalist Values, and the Sacralization of Subjective Life in Egypt. International Journal of Middle East Studies 47: 663-80. [CrossRef]

Kostecki, Wojciech, and Aldona Maria Piwko. 2021. Legislative Actions of the Republic of Poland Government and Religious Attitudes of Muslims in Poland during the COVID-19 Pandemic. Religions 12: 335. [CrossRef]

Krotofil, Joanna, Anna Piela, Katarzyna Górak-Sosnowska, and Beata Abdallah-Krzepkowska. 2021. Theorizing the Religious Habitus in the Context of Conversion to Islam among Polish Women of Catholic Background. Sociology of Religion 82: 257-80. [CrossRef]

Kühle, Lene. 2021. Danish Muslims during COVID-19: Religion and pandemics in a postsecular society. Tidsskrift for Islamforskning 15: 13-39. [CrossRef]

Linskens, Ella. 2020. For Muslim converts, an isolated Ramadan under coronavirus lockdown is nothing new. The New Arab, April 23. Available online: https:/ / english.alaraby.co.uk/features/muslim-converts-isolated-ramadan-nothing-new (accessed on 14 September 2021).

Lucero, Leanna. 2017. Safe spaces in online places: Social media and LGBTQ youth. Multicultural Education Review 9: 117-28. [CrossRef]

Mahmood, Saba. 2001. Rehearsed Spontaneity and the Conventionality of Ritual: Disciplines of Şalat. American Ethnologist 28: 827-53. [CrossRef]

Mahmood, Saba. 2005. Politics of Piety: The Islamic Revival and the Feminist Subject. Princeton: Princeton University Press.

Makki, Hind. 2020. Coronavirus restrictions on mosques bring women to the fore. Religion News Service, May 18. Available online: https:/ / religionnews.com/2020/05/18/coronavirus-restrictions-on-mosques-bring-women-to-the-fore/ (accessed on 14 September 2021).

Mansouri, Fehti. 2020. On the Discursive and Methodological Categorisation of Islam and Muslims in the West: Ontological and Epistemological Considerations. Religions 11: 501-21. [CrossRef]

Marsden, Magnus. 2005. Living Islam: Muslim Religious Experience in Pakistan's North-West Frontier. Cambridge and New York: Cambridge University Press.

McClintock, Anne. 1992. The Angel of Progress: Pitfalls of the Term "Post-Colonialism". Social Text 31-32: 84-98. [CrossRef]

McGuire, Meredith B. 2008. Lived Religion: Faith and Practice in Everyday Life. Oxford and New York: Oxford University Press.

Moosavi, Leon. 2012. British Muslim Converts Performing 'Authentic Muslimness'. Performing Islam 1: 103-28. [CrossRef]

Nyhagen, Line. 2019. Mosques as Gendered Spaces: The Complexity of Women's Compliance with, And Resistance to, Dominant Gender Norms, And the Importance of Male Allies. Religions 10: 321. [CrossRef]

O'Brien, John. 2018. Keeping It Halal: The Everyday Lives of Muslim American Teenage Boys. Princeton: Princeton University Press.

Peek, Lori. 2005. Becoming Muslim: The Development of a Religious Identity. Sociology of Religion 66: 215-42. [CrossRef]

Piwko, Aldona Maria. 2021. Islam and the COVID-19 Pandemic: Between Religious Practice and Health Protection. Journal of Religion and Health. Epub ahead of print. [CrossRef]

Poole, Elizabeth, and Milly Williamson. 2021. Disrupting or reconfiguring racist narratives about Muslims? The representation of British Muslims during the Covid crisis. Journalism. Epub ahead of print. [CrossRef]

Prickett, Pamela J. 2015. Negotiating Gendered Religious Space: The Particularities of Patriarchy in an African American Mosque. Gender E Society 29: 51-72. [CrossRef]

Rajan, Benson, and Shreya Venkatraman. 2021. Insta-hate: An exploration of Islamophobia and right-wing nationalism on Instagram amidst the COVID-19 pandemic in India. Journal of Arab \& Muslim Media Research 14: 71-91. [CrossRef]

Reja, Urša, Katja L. Manfreda, Valentina Hlebec, and Vasja Vehovar. 2003. Open-ended vs. Close-ended Questions in Web Questionnaires. Developments in Applied Statistics 19: 159-77.

Ripon, Rezaul K., Sadia S. Mim, Antonio E. Puente, Sahadat Hossain, Md Mahmudul H. Babor, Showkot A. Sohan, and Naeem Islam. 2020. COVID-19: Psychological effects on a COVID-19 quarantined population in Bangladesh. Heliyon 6: e05481. [CrossRef]

Safi, Omid. 2003. What Is Progressive Islam? ISIM Newsletter 13: 48-49.

Salem, Jackleen. 2017. Ramadan, Eid al-fitr, and Eid al-Adha: Fasting and Feasting. In The Practice of Islam in America: An Introduction. Edited by Edward E. Curtis IV. New York: New York University Press, pp. 83-103. 
Schielke, Samuli. 2009. Being good in Ramadan: Ambivalence, fragmentation, and the moral self in the lives of young Egyptians. Journal of the Royal Anthropological Institute 15: S24-S40. [CrossRef]

Shielke, Samuli. 2010. Second thoughts about the anthropology of Islam, or how to make sense of grand schemes in everyday life. ZMO Working Papers 2: 1-16. Available online: https:/ /nbn-resolving.org/urn:nbn:de:0168-ssoar-322336 (accessed on 14 September 2021).

Schmidt, Katharina, Tobias Gummer, and Joss Roßmann. 2020. Effects of Respondent and Survey Characteristics on the Response Quality of an Open-Ended Attitude Question in Web Surveys. Methods, Data, Analyses 14: 3-34. [CrossRef]

Sedgwick, Mark. 2014. Islam and Popular Culture. In Islam in the Modern World. Edited by Jeffrey T. Kenney and Ebrahim Moosa. London: Routledge, pp. 279-98.

Selby, Jennifer A., Amélie Barras, and Lori G. Beaman. 2018. Beyond Accommodation: Everyday Narratives of Muslim Canadians. Vancouver: UBC Press.

Shaw, Daniel S., and Robert E. Emery. 1987. Parental conflict and other correlates of the adjustment of school-age children whose parents have separated. Journal of Abnormal Child Psychology 15: 269-81. [CrossRef] [PubMed]

Siraj, Asifa. 2012. Looking 'In' from the 'Outside': The Methodological Challenges of Researching Minority Ethnic Gay Men and Lesbian Women. In The Ashgate Research Companion to Contemporary Religion and Sexuality. London: Routledge, pp. 59-77.

Thomas, Justin, and Mariapaola Barbato. 2020. Positive Religious Coping and Mental Health among Christians and Muslims in Response to the COVID-19 Pandemic. Religions 11: 498. [CrossRef]

Thompson, Katrina Daly. 2020. Making Space for Embodied Voices, Diverse Bodies, and Multiple Genders in Nonconformist Friday Prayers: A Queer Feminist Ethnography of Progressive Muslims' Performative Intercorporeality in North American Congregations. American Anthropologist 122: 876-90. [CrossRef]

Thompson, Ross. 2017. The Interfaith Imperative: Religion, Dialogue, and Reality. Eugene: Wipf and Stock Publishers.

Thurston, Alex. 2020. Islamic Responses to COVID-19. POMEPS. Available online: https:// pomeps.org/islamic-responses-to-covid-19 (accessed on 14 September 2021).

Versteeg, Peter, and Johan Roeland. 2012. Contemporary Spirituality and the Making of Religious Experience: Studying the Social in an Individualized Religiosity. Fieldwork in Religion 6: 120-33. [CrossRef]

Vogels, Emily A. 2021. Digital divide persists even as Americans with lower incomes make gains in tech adoption. Pew Research Center, June 22. Available online: https:/ / www.pewresearch.org/fact-tank/2021/06/22/digital-divide-persists-even-as-americanswith-lower-incomes-make-gains-in-tech-adoption/ (accessed on 14 September 2021).

Williamson, W. Paul. 2018. The Experience of Muslim Prayer: A Phenomenological Investigation. Pastoral Psychology 67: 547-62. [CrossRef]

Wittgenstein, Ludwig. 1968. Philosophical Investigations. Oxford: Basil Blackwell. First published 1953.

Wolin, Steven J., and Linda A. Bennett. 1984. Family Rituals. Family Process 23: 401-20. [CrossRef] 